\section{The epidemiology of Clostridium difficile infection in Romania: what we know, or do not know and why?}

\section{To the Editor,}

We read with interest the recent article by Lupse et al [1] and we would like to make a few comments. The authors evaluated the predictors of a first recurrence in Clostridium difficile infection (CDI) and found that $20 \%$ of their patients had recurrent infection, and the risk of first recurrence was significantly higher in those older than 70 who also received proton pump inhibitors; these results are in accordance with the literature data. Though we agree with most of the authors' comments, there are some points where we are of a different opinion.

Firstly, the authors stated that their study is "the first on CDI epidemiology in Romania" and that they "observed an increase in CDI cases in Romanian hospitals as well as worldwide". But their study is not an epidemiological one, as they reported the number of patients admitted during 22 months and made no comparison with a similar previous period to see whether CDI incidence really increased, and more important, to what degree. Is CDI more frequent in our country, or just better diagnosed? Do we know the real dimensions of CDI in Romania? As epidemiological studies regarding the incidence of CDI in our country are lacking, we fear that there appears to be more questions than answers.

Secondly, we all know that, over the last decade, CDI has increased worldwide both in incidence and severity, and this is clearly proved by many well performed epidemiological studies [2]. Most likely, the same trend has been present in our country, even if to a lesser extent, but most cases were underdiagnosed, either because of low levels of awareness for CDI among clinicians or misdiagnosed in the absence of sensitive diagnostic tests. Illustratively, in our institution, after the first case diagnosed with pseudomembranous colitis in 2011 [3], number of tests ordered for $C$. difficile by our physicians and, subsequently, patients diagnosed with CDI have significantly increased.
Thirdly, we do not know the real dimension of CDI in Romania, and we will not know it until well-designed epidemiological studies are carried out. With the exception of some case-reports $[3,4]$, we were unable to find one single epidemiological study concerning CDI. There is, however, one hospital-based survey regarding CDI in Europe, in which 5 Romanian hospitals participated together with 97 hospitals from 34 European countries [5]. Results are certainly not representative for CDI incidence in Romania, but illustrate the lack of awareness; thus, only 3 Romanian patients per 10,000 patient-days were tested as compared with 38 from Hungary, 115 from the UK, or 141 from Finland.

Watery diarrhea is the cardinal symptom in CDI and, therefore, if this symptom is present, especially in relation with the use of antibiotics, CDI must be suspected and any physician should ask a stool test for C. difficile. As we already mentioned, there has been a low level of awareness for CDI among our physicians, and this situation could be improved by implementing the recommendations of current guidelines [6]. It should be underlined that other countries too have been confronted in the past with the same low level of suspicion regarding CDI $[7,8]$. Thus, in the USA, $69 \%$ of internal medicine residents were not aware of the existence of CDI in outpatient settings and would not test for this infection [8].

Finally, we may conclude that fighting this pathogen termed C. difficile is difficult, but we can achieve success only by increasing clinical suspicion for CDI in patients with unexplained watery diarrhea, systematically implementing guidelines in our routine clinical practice, as well as supporting education at a wide level.

Anca Trifan $^{1,2}$, Camelia Cojocariu ${ }^{1,2}$, Oana Stoica ${ }^{1}$, Carol Stanciu ${ }^{2}$ 1) Gr. T. Popa University of Medicine and Pharmacy; 2) St. Spiridon Emergency Hospital, Institute of Gastroenterology and Hepatology, Iasi, Romania

Corresponding author: Carol Stanciu; stanciucarol@yahoo.com

Conflicts of interest: None. 


\section{REFERENCES}

1. Lupse M, Flonta M, Cioara A, Filipescu I, Todor N. Predictors of first recurrence in Clostridium difficile-associated disease. A study of 306 patients hospitalized in a Romanian tertiary referral center. J Gastrointestin Liver Dis 2013;22:379-403.

2. Khanna S, Pardi DS. The growing incidence and severity of Clostridium difficile infection in inpatient and outpatient settings. Expert Rev Gastroenterol Hepatol 2010;4:409-416.

3. Cojocariu C, Danciu M, Chiriac S, Trifan A, Stanciu C. A 72-year old man with diarrhea, hypoproteinemia, edema and ascites. J Gastrointestin Liver Dis 2011;20:314.

4. Gheorghe L, Vadan R, Cerban R, Gheorghe C. Clostridium difficile infection in gastroenterology settings: more frequent or better diagnosed? J Gastrointestin Liver Dis 2012;21:110-111.

5. Bauer MP, Notermans DW, van Benthem BH, et al. Clostridium difficile infection in Europe: a hospital-based survey. Lancet 2011;377:63-73.

6. Cohen SH, Gerding DN, Johnson S, et al. Clinical practice guideline for Clostridium difficile infection in adults: 2010 update by the society for healthcare epidemiology of America (SHEA) and the infectious disease society of America (IDSA). Infect Control Hosp Epidemiol 2010;31:431-455.

7. Alcalá L, Martin A, Marin M, et al. The undiagnosed cases of Clostridium difficile infection in a whole nation: where is the problem? Clin Microbiol Infect 2012;18:204-213.

8. Navaneethan U, Schauer D, Giannella R. Awareness about Clostridium difficile infection among internal medicine residents in the United States. Minerva Gastroenterol Dietol 2011;57:231-240.

\section{Reply,}

We are thankful to Trifan and collaborators for their interest in our recently published study and their comments.

Epidemiology of $C$. difficile infection is a matter of debate everywhere across Europe. Although surveillance of $C$. difficile infection in Europe is now a requirement of the European Commission, reporting it is not standardized or mandatory [1]. C. difficile infection is not a reportable condition in Romania and there are no national epidemiological data. Starting with 2013, the National Center for Surveillance and Control of Transmissible Diseases introduced a strategy to reduce the incidence of $C$. difficile infection in Romanian hospitals [2]. Before publication of our study [3], no information regarding the dimension of the problem in Romania was published. The Romanian hospitals referred in the article by Bauer et al were not hospitals of infectious diseases, in contrast with our hospital, so that relevant data for the epidemiology of the disease are lacking [4]. We reported 306 patients treated over 22 months, i.e. an average of 14 patients per month in a population of 691,100 of Cluj County (2011 census), suggesting an incidence of 24.15 per 100,000 population. The study was not intended to be an epidemiological study, but instead to present the characteristics of $C$. difficile infection in Romania concerning gender, age distribution, risk factors, treatment and outcome as well as the factors predicting recurrence of the disease.

As we have been testing for $C$. difficile toxins A and B for more than 5 years, we also observed a significant increase of cases in the last 2 years, related to small outbreaks. Whether the trend in our hospital is representative for Romania is difficult to say but, for sure, as Trifan and colleagues mentioned, the awareness for this disease has increased.

Regarding the clinical presentation of $C$. difficile infection, we should always be aware of the risk factors for the disease. The clinical symptoms and signs of infection with toxinproducing strains of $C$. difficile range from symptomless carriage to mild or moderate diarrhea, and to fulminant and sometimes even fatal pseudomembranous colitis. Expensive laboratory diagnostic tests, longterm antibiotic treatment, high mortality and recurrence rates are responsible for increasing hospital costs. Obviously, more important than diagnosis is the prevention of the disease.

We hope to come forward with more information on the epidemiology of the disease by collaborating with other Romanian hospitals, as we are in total agreement with Trifan and colleagues that implementation of guidelines and an increase of the level of awareness for this disease are mandatory in the clinical practice.

\section{Mihaela Lupse}

Department of Infectious Diseases, Iuliu Hatieganu University of Medicine and Pharmacy, Cluj-Napoca, Romania

Corresponding author: Mihaela Lupse; mihaela.lupse@yahoo.com

Conflicts of interest: None.

\section{REFERENCES}

1. Jones AM, Kuijper EJ, Wilcox MH. Clostridium difficile: a European perspective. J Infect 2013;66:115-128.

2. Centrul National de Supraveghere si Control al Bolilor Transmisibile. http://www.insp.gov.ro/cnscbt/

3. Lupse M, Flonta M, Cioara A, Filipescu I, Todor N. Predictors of First Recurrence in Clostridium difficile-associated Disease. A study of 306 Patients Hospitalized in a Romanian Tertiary Referral Center. J Gastrointestin Liver Dis 2013;22:379-403.

4. Bauer MP, Notermans DW, van Benthem BH, et al. Clostridium difficile infection in Europe: a hospital-based survey. Lancet 2011;377:63-73.

\section{Fibrin-glue-sealed liver biopsy: indications, complications and results}

\section{To the Editor,}

Liver biopsy is a key diagnostic tool for many patients with known or suspected liver disease. It is considered a relatively safe procedure, with a complication rate between 0 and $5.3 \%$ according to published studies [1]. Mortality is also very low, not exceeding $0.5 \%$ in any of the series analyzed [1-3]. Patients at increased risk of developing complications are those with coagulation disorders, platelet dysfunction or ascites. To reduce morbidity and mortality rates in these cases, different strategies have been developed such as transjugular biopsy or biopsies sealed with hemostatic materials [4-9]. The aim of the present study was to analyze our experience with fibrin-gluesealed liver biopsies (FGSLB) in patients at increased risk of complications. 
Our study included 88 FGSLBs performed in 76 patients in a tertiary center from February 1999 to May 2012. We used 14G Tru-Cut needles, and an adhesive material composed of fibrinogen and human thrombin (Tissucol) as a sealing agent. The puncture site was anesthetized using 3\% mepivacaine, and biopsies were performed with ultrasound guidance. After performing the sealed biopsy, all patients remained at least 24 hours under hospital observation.

Collected parameters were obtained through ultrasound reports and computerized medical database. The study protocol was approved by the Ethics Committee of Clinical Research and all patients signed an informed consent form prior to biopsy.

Sixty-eight (77.3\%) patients were male and the mean age was $49 \pm 11.7$ years. Biopsy indications were graft dysfunction post liver transplantation (61.4\%, 54 cases), HBV infection (6.8\%), HCV infection (3.4\%) and other conditions such as suspected chronic liver disease or abnormal liver function tests $(27.3 \%)$. Indications for sealing were thrombocytopenia (54.5\%), coagulation disorders (20.4\%), antiplatelet therapy $(10.2 \%)$ and other reasons, such as ascites and/or increased bilirubin level (15.9\%).

One single pass was needed in 81 patients (92\%), and sufficient liver tissue was obtained in $94.3 \%$ of cases. The average sample length was $1.4 \mathrm{~cm}$. Complication rate was $7.9 \%$ (7 patients). Five were minor complications (5.7\%), and two $(2.2 \%)$ were major: self-limited hemoperitoneum that required transfusion. No deaths occurred.

Despite limitations regarding sample size, the observational design and the lack of a control group (circumstances difficult to overcome due to ethical reasons), these results suggest that FGSLB could be safe and effective for obtaining adequate histological samples. This fact could be particularly important when the biopsy, necessary for the clinical decision, is carried out under unfavorable circumstances.

Rosa M. Martín-Mateos, Antonio López-San Román, Concepción García-Sánchez, Fernando García-Hoz, Luis A. Gil-Grande, Elena Garrido Gómez, Miguel García-González

Department of Gastroenterology. Hospital Universitario Ramón y Cajal, Madrid 28034, Spain

Corresponding author: Rosa M. Martín-Mateos rosam.martinma@salud.madrid.org

Conflicts of interest: None.

\section{REFERENCES}

1. Rockey DC, Caldwell SH, Goodman ZD, Nelson RC, Smith AD; American Association for the Study of Liver Diseases. Liver biopsy. Hepatology 2009;49:1017-1044.

2. Grant A, Neuberger J. Guidelines on the use of liver biopsy in clinical practice. British Society of Gastroenterology. Gut 1999;45 Suppl 4:IV1-IV11.

3. Cuenca Morón B, García González M, Garre Sánchez MC, et al. In Díaz de Santos. (ed.). Tratado de ultrasonografía abdominal. Madrid 2010,425-432

4. Tobin MV, Gilmore IT. Plugged liver biopsy in patients with impaired coagulation. Dig Dis Sci 1989;34:13-15.
5. Kamphuisen PW, Wiersma TG, Mulder CJ, de Vries RA. Pluggedpercutaneous liver biopsy in patients with impaired coagulation and ascites. Pathophysiol Haemost Thromb 2002;32:190-193.

6. Riley SA, Ellis WR, Irving HC, Lintott DJ, Axon AT, Losowsky MS. Percutaneous liver biopsy with plugging of needle track: a safe method for use in patients with impaired coagulation. Lancet 1984;2:436.

7. Sawyerr AM, McCormick PA, Tennyson GS, et al. A comparison of transjugular and plugged-percutaneous liver biopsy in patients with impaired coagulation. J Hepatol 1993;17:81-85.

8. Atar E, Ben Ari Z, Bachar GN, et al. A comparison of transjugular and plugged-percutaneous liver biopsy in patients with contraindications to ordinary percutaneous liver biopsy and an „in-house” protocol for selecting the procedure of choice. Cardiovasc Intervent Radiol 2010;33:560-564.

9. Albéniz Arbizu E, López San Román A, Garcia González M, et al. Fibrin-glue sealed liver biopsy in patients with a liver transplantation or in liver transplantation waiting list: preliminary results. Transplant Proc 2003;35:1911-1912.

\section{Increased levels of serum amyloid A during the early phase of hepatitis $C$ treatment with interferon are associated with sustained virologic response - a pilot study}

\section{To the Editor,}

Clearance of hepatitis $\mathrm{C}$ virus (HCV) infection has been associated with a strong, broadly-targeted $\mathrm{T}$ cell response [1, 2]. Activation of T-cells by HCV proteins results in production of soluble cytokines, which in turn induce various acute-phase proteins including serum amyloid A (SAA). It has been shown that SAA inhibits replication of HCV in vitro by blocking virus entry into the hepatocytes [3]. We therefore hypothesized that SAA levels measured during the early phases of HCV-therapy might predict the success of antiviral treatment.

We studied 35 consecutive patients with chronic hepatitis C (males/females: 20/15; mean age \pm SD: $42.0 \pm 8.5$, range: 23 61 years), who had been treated with peginterferon (pegIFN) plus ribavirin at our centre. HCV genotype (GT)-1 was most prevalent $(n=17)$, followed by GT-3 $(n=9)$, GT-4 $(n=7)$, and GT-2 ( $n=1)$; one patient was coinfected with GT-1 and GT-4. All patients received pegIFN $\alpha-2 \mathrm{a} 180 \mu \mathrm{g}$ once weekly plus ribavirin (1000-1200mg daily for GT-1/4 and $800 \mathrm{mg}$ daily for GT-2/3). In patients with GT-1 or 4 , treatment duration ranged from 24 to 72 weeks and was adapted to the kinetics of HCV-RNA during therapy as described previously [4]. In patients with GT-2 or 3, treatment duration was 24 weeks. Plasma HCV-RNA levels were measured by COBAS TaqMan HCV-RNA assay, version 2.0 (Roche).

Plasma samples that were collected at different time points of treatment were tested for levels of acute-phase reactants including high-sensitivity C-reactive protein (hs-CRP), fibronectin (FNC), human interleukin-6 (IL-6), and SAA as described previously [5].

We observed a sustained virologic response (SVR) in $25(71 \%)$ patients, relapses in $4(11 \%)$, a partial response in $4(11 \%)$, and null responders were $2(6 \%)$. In patients with SVR, SAA-levels increased significantly from $4.8 \pm 2.8 \mathrm{mg} / \mathrm{l}$ at baseline to a peak concentration of $14.5 \pm 21.7 \mathrm{mg} / \mathrm{l}$ between 


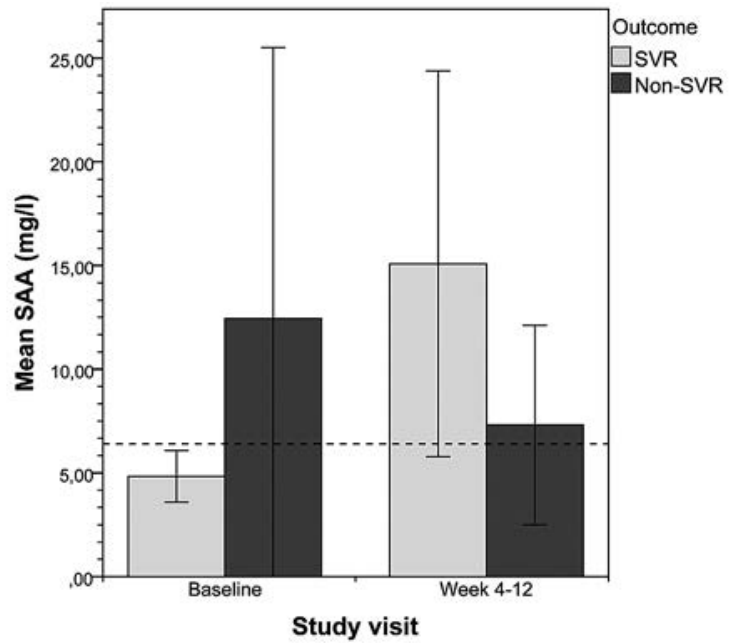

Fig. 1. Serum amyloid A level in patients with chronic hepatitis $\mathrm{C}$ under treatment with pegIFN/ribavirin. The dashed line indicates the cut-point for defining normal vs increased levels of SAA.

week 4 and week 12 ( $\mathrm{p}<0.05$, Student's paired t test). In contrast, SAA-levels showed no significant change in patients without SVR $(15.1 \pm 18.6 \mathrm{mg} / \mathrm{l}$ at baseline versus $7.1 \pm 5.9 \mathrm{mg} / \mathrm{l}$, week 4-12, Fig. 1). Plasma values of hs-CRP, fibronectin and IL-6 remained within normal limits during the whole treatment period in all patients.

In summary, this pilot study indicates that a significant increase in plasma levels of SAA during the early phase of pegIFN/ribavirin therapy is associated with SVR. In contrast, serum levels of the other acute-phase reactants evaluated were not associated with hepatitis $C$ viral kinetics, a finding in concordance with previous studies $[6,7]$. At present, it is unclear whether the observed increase in SAA levels is associated with treatment success because of the antiviral properties of SAA (viral elimination by blocking viral entry into hepatocytes) [8] or it is a surrogate marker for an effective immune response to $\mathrm{HCV}$ infection triggered by treatment with interferon. The potential role of SAA as a predictor of SVR in HCV-infected patients should be evaluated in future prospective trials.

Michael Gschwantler ${ }^{1}$, Melisa Dulic ${ }^{1}$, Emina Dulic-Lakovic ${ }^{1}$, Remy Schwarzer ${ }^{1}$, Franz Rieder ${ }^{2}$, Wolfgang Graninger ${ }^{2}$, Christoph Steininger ${ }^{2}$

1) Department of Internal Medicine IV, Wilhelminenspital; 2) Department of Medicine I, Medical University of Vienna, Vienna, Austria

Corresponding author: Christoph Steininger christoph.steininger@meduniwien.ac.at

Conflicts of interest: None to declare. This study waas supported by a grant of the Austrian Science Fund (grant nr. P25353-B21).

\section{REFERENCES}

1. Thimme R, Bukh J, Spangenberg HC, et al. Viral and immunological determinants of hepatitis $\mathrm{C}$ virus clearance, persistence, and disease. Proc Natl Acad Sci U S A 2002;99:15661-15668.
2. Pestka JM, Zeisel MB, Blaser E, et al. Rapid induction of virusneutralizing antibodies and viral clearance in a single-source outbreak of hepatitis C. Proc Natl Acad Sci U S A 2007;104:6025-6030.

3. Lavie M, Voisset C, Vu-Dac N, et al. Serum amyloid A has antiviral activity against hepatitis $\mathrm{C}$ virus by inhibiting virus entry in a cell culture system. Hepatology 2006;44:1626-1634.

4. Ferenci P, Laferl H, Scherzer $M$, et al. Peginterferon alfa-2a/ribavirin for 48 or 72 weeks in hepatitis $\mathrm{C}$ genotype 1 and 4 patients with slow virologic response. Gastroenterology 2010; 138: 503-512.

5. Steininger C, Graninger W, Zoufaly A, et al. Aymptomatic CMV viremia is associated with increased levels of serum amyloid $\mathrm{A}$ in patients with advanced HIV-infection. Eur J Med Res 2008;13:304-308.

6. Lannergard A, Larsson A, Kragsbjerg P, Friman G. Correlations between serum amyloid A protein and C-reactive protein in infectious diseases. Scand J Clin Lab Invest 2003;63:267-272.

7. Miwata H, Yamada T, Okada M, Kudo T, Kimura H, Morishima T. Serum amyloid A protein in acute viral infections. Arch Dis Child 1993;68:210-214.

8. Cai Z, Cai L, Jiang J, Chang KS, van der Westhuyzen DR, Luo G. Human serum amyloid A protein inhibits hepatitis C virus entry into cells. J Virol 2007;81:6128-6133.

\section{Tumor characteristics and surgical therapy influence the outcome of gastrointestinal stromal tumors}

\section{To the Editor,}

Gastrointestinal stromal tumors (GIST) are the most common mesenchymal neoplasms of the gastrointestinal tract. The three main characteristics for predicting how GIST will behave are size, mitotic rate and location [1]. Tumors with low mitotic counts ( $<5 / 50$ HPFs) and a diameter $<2$ $\mathrm{cm}$ generally exhibit a benign behavior, while tumors with a diameter $>10 \mathrm{~cm}$ and high mitotic counts (> $5 / 50 \mathrm{HPFs}$ ) are associated with malignant behavior. Complete surgical resection is the primary treatment modality for GIST. Total excision of the tumor is the most significant factor for a good outcome and can be accomplished in 40 to $60 \%$ of all GIST patients [2]. Nevertheless, around $50 \%$ of patients tend to develop tumor recurrence and the reported 5-year survival is approximately $50 \%$ [3]. The median survival of recurrent GIST after surgical resection is 15 months in the pre-imatinib era [4]. Conventional chemotherapy for the treatment of GIST has a response rate of 5\% [5]. Imatinib is a selective inhibitor of specific TK, including KIT, platelet-derived growth factor receptor alpha (PDGFR-a), ARG, c-FMS, ABL and BCR-ABL, and is currently the standard first-line treatment for patients with KIT-positive unresectable or metastatic GIST, or both $[2,6]$.

In our unit, from January 2002 until February 2009, 33 patients diagnosed with GIST were included in an observational, prospective study. The diagnosis of GIST was based on light microscopy features and membrane positivity for CD117 (cKIT) by immunohistochemistry. The clinical and pathological features of the study group are summarized in Table I. Based on the size of the primary tumor, mitotic index and Fletcher's criteria, the tumors were classified into groups with very low $(n=3)$, low $(n=5)$, intermediate $(n=6)$ 
Table I. Characteristics of the patients with GISTs

\begin{tabular}{ll}
\hline Age (years) & \\
Mean (range) & $59.2(40-81)$ \\
Gender (n, \%) & $15(46)$ \\
Male & $18(54)$ \\
Female & \\
Location of tumor (n, \%) & $17(52)$ \\
Stomach & $4(12)$ \\
Duodenum & $10(30)$ \\
Small bowel & $1(3)$ \\
Large bowel & $1(3)$ \\
Other & \\
Histopathological subtype (n, \%) & \\
Spindle cell & $10(30)$ \\
Epithelioid & $4(12)$ \\
Mixed & $19(58)$ \\
Symptoms (\%) & \\
Abdominal pain & 36 \\
Gastrointestinal bleeding & 58 \\
Appetite and weight loss & 43 \\
Abdominal mass & 6 \\
Asthenia & 57 \\
Nausea & 27 \\
Diarrhea & 3 \\
Surgical treatment (n, \%) & \\
Complete resection & $29(88)$ \\
Enucleation & $4(13)$ \\
\hline &
\end{tabular}

and high $(\mathrm{n}=7)$ risk. Progression-free survival (PFS) in the patients with primary gastric GIST was not significantly longer than the PFS in other locations $(p=0.28)$. The PFS differed significantly with the increasing risk as shown by the tumor dimension and mitotic rate $(\mathrm{p}=0.0001)$. The patients with an increased risk of tumor recurrence received chemotherapy with Imatinib. Patients treated with Imatinib had a higher PFS and a higher overall survival (OS) compared to patients who had not received chemotherapy ( $\mathrm{p}=0.021$ and $\mathrm{p}=0.005$, respectively). The type of surgical intervention did not influence the PFS and OS of patients with GIST ( $\mathrm{p}=0.28)$.

In conclusion, our data, even on a small number of patients, add to the body of the published literature confirming that survival depends on the location of the tumor, risk of malignancy and type of treatment. The multidisciplinary approach is essential in the assessment of accurate diagnosis of this disease and for the improvement of the therapeutic approach.

Nadim Al Hajjar ${ }^{1,2}$, Alina Habic ${ }^{3}$, Adrian Bartos ${ }^{1,2}$, Dana Crisan ${ }^{3}$ 1) 3rd Surgical Clinic, Iuliu Hatieganu University of Medicine and Pharmacy; 2) Surgery Department; 3) Gastroenterology Department, Regional Institute of Gastroenterology and Hepatology, Cluj-Napoca, Romania

Corresponding author: Alina Habic; alina.habic@yahoo.com

Conflicts of interest: None.

\section{REFERENCES}

1. Miettinen M, Lasota J. Gastrointestinal stromal tumors: pathology and prognosis at different sites. Semin Diagn Pathol 2006;23:70-83.
2. Bednarski BK, Pisters PW, Hunt KK. The role of surgery in the multidisciplinary management of patients with localized gastrointestinal stromal tumors. Expert Rev Anticancer Ther 2012;12:1069-1078.

3. Vendettuoli M, Pironi D, Pontone S, et al. Gastrointestinal stromal tumors treatment in the Imatinib era. The role of fair indication. .Minerva Chir 2012;67:165-173.

4. Tsukuda K, Hirai R, Miyake T, et al. The outcome of gastrointestinal stromal tumors (GISTs) after a surgical resection in our institute. Surg Today 2007;37:953-957.

5. Downs-Kelly E, Rubin BP. Gastrointestinal stromal tumors: molecular mechanisms and targeted therapies. Patholog Res Int 2011;2011:708596.

6. Call J, Walentas CD, Eickhoff JC, Scherzer N. Survival of gastrointestinal stromal tumor patients in the imatinib era: life raft group observational registry. BMC Cancer 2012;12:90.

\section{Is there a role for chromoendoscopy in the diagnosis of coeliac disease?*}

\section{To the Editor,}

Endoscopic markers of villous atrophy have a low sensitivity for the diagnosis of coeliac disease (CD). Small historical studies have suggested that chromoendoscopy can significantly increase their accuracy (Table I). However, these were single endoscopists in a research environment. Modern magnification techniques may enhance detection but this technology is not widely available internationally. For this reason we assessed the role of chromoendoscopy in patients presenting for endoscopy.

Patients undergoing oesogastroduodenoscopy were prospectively recruited from endoscopy department. Patients were divided into two groups: patients with no previous history of CD (Group 1, n=300) and patients with established CD (Group 2, $n=45$ ). During the procedure, the endoscopic findings were reported before and after indigo carmine dye spray use in the duodenum. All patients had tissue tranglutaminase antibody (TTG), endomysial antibody (EMA), IgA level and duodenal biopsies (>4) evaluated.

In Group 1, 89/300 (30\%) were newly diagnosed CD patients with endoscopic markers identified in $42 \%(37 / 89)$. Chromoendoscopy identified a further 11 patients $(48 / 89$, $54 \%)(\mathrm{P}=0.001)$. Sensitivity, specificity, positive and negative predictive values for standard endoscopy to detect CD were $42 \%, 98 \%, 90 \%$ and $80 \%$, respectively. For chromoendoscopy they were $54 \%, 97 \%, 89 \%$ and $83 \%$, respectively. For TTG, $89 \%, 78 \%, 63 \%, 94 \%$ and for EMA $78 \%, 97 \%, 91 \%$ and $91 \%$, respectively. In Group 2, 17/45 (38\%) patients had Marsh 3 duodenal changes; chromoendoscopy did not significantly increase detection $(\mathrm{P}=0.5)$.

Although chromoendoscopy is inexpensive, easy to use and improves the identification of endoscopic markers, the accuracy for the diagnosis of CD was shown to be poorer than the current serological testing. Therefore, chromoendoscopy cannot be recommended for routine clinical practice.

Alexander J. Johnston, Matthew Kurien, Anastasios Avgerinos, Peter D. Mooney, David S. Sanders

Department of Gastroenterology, Royal Hallamshire Hospital, Sheffield, United Kingdom 
Table I. Comparison of all published studies utilising chromoendoscopy for the diagnosis of coeliac disease

\begin{tabular}{|c|c|c|c|c|c|c|c|c|}
\hline Author & Year & $\begin{array}{l}\text { Country } \\
\text { of Origin }\end{array}$ & Methodology & $\begin{array}{l}\text { Number of } \\
\text { Patients }\end{array}$ & $\begin{array}{l}\text { Number of } \\
\text { Endoscopists }\end{array}$ & Comparators & Magnification & Result \\
\hline $\begin{array}{l}\text { Stevens } \\
\text { and } \\
\text { McCarthy } \\
{[1]}\end{array}$ & 1976 & Ireland & $\begin{array}{c}\text { Applied } 0.4 \% \\
\text { indigo carmine }\end{array}$ & $\begin{array}{c}15 \\
\text { (8 with CD) }\end{array}$ & Not stated & $\begin{array}{l}\text { Endoscopic } \\
\text { markers }\end{array}$ & $\begin{array}{l}\text { No } \\
\text { magnification }\end{array}$ & $\begin{array}{l}\text { No comparison with } \\
\text { standard endoscopy } \\
\text { Sensitivity and } \\
\text { specificity of } 100 \%\end{array}$ \\
\hline $\begin{array}{l}\text { Siegel et al } \\
{[2]}\end{array}$ & 1997 & USA & $\begin{array}{c}\text { Applied } 0.1 \% \\
\text { indigo carmine }\end{array}$ & $\begin{array}{c}34 \\
\text { (17 with VA) }\end{array}$ & Not stated & $\begin{array}{l}\text { Endoscopic } \\
\text { markers } \\
\text { with villous } \\
\text { atrophy }\end{array}$ & Up to $x 35$ & $\begin{array}{l}\text { Improved identification } \\
\text { of endoscopic markers } \\
\text { compared to standard } \\
\text { endoscopy } \\
\text { Sensitivity and } \\
\text { specificity of } 94 \% \text { and } \\
88 \% \text { respectively }\end{array}$ \\
\hline $\begin{array}{l}\text { Kiesslich et } \\
\text { al [3] }\end{array}$ & 2003 & Germany & $\begin{array}{l}\text { Applied } 10 \mathrm{ml} \\
0.4 \% \text { indigo } \\
\text { carmine each to } \\
\text { D1 and D2 }\end{array}$ & $\begin{array}{c}54 \\
\text { (4 with VA) }\end{array}$ & Not stated & $\begin{array}{l}\text { Endoscopic } \\
\text { markers }\end{array}$ & $\begin{array}{l}\text { No } \\
\text { magnification } \\
\text { for } 27 \text { patients } \\
\text { and up to x105 } \\
\text { for the other } 27 \\
\text { patients }\end{array}$ & $\begin{array}{l}\text { Endoscopic markers } \\
\text { seen before and after } \\
\text { dye in all } 4 \text { patients with } \\
\text { villous atrophy }\end{array}$ \\
\hline $\begin{array}{l}\text { Morishita } \\
\text { et al [4] }\end{array}$ & 2003 & Japan & $\begin{array}{c}\text { Applied } 0.1 \% \\
\text { indigo carmine }\end{array}$ & $\begin{array}{c}1 \\
\text { (1 with } \mathrm{CD})\end{array}$ & 1 & $\begin{array}{l}\text { Endoscopic } \\
\text { markers }\end{array}$ & Up to $\mathrm{x} 40$ & $\begin{array}{l}\text { Endoscopic markers } \\
\text { seen before and after dye }\end{array}$ \\
\hline $\begin{array}{l}\text { Iovino et } \\
\text { al [5] }\end{array}$ & 2013 & Italy & $\begin{array}{c}\text { Instilled and } \\
\text { aspirated } 180 \mathrm{ml} \\
\text { water, followed } \\
\text { by } 20-30 \mathrm{ml} 10 \% \\
\mathrm{~N} \text {-acetylcysteine } \\
\text { and } \sim 30 \mathrm{ml} 0.4 \% \\
\text { indigo carmine }\end{array}$ & $\begin{array}{c}77 \\
\text { (41 with CD) }\end{array}$ & 1 & $\begin{array}{l}\text { Direct } \\
\text { visualisation } \\
\text { of mucosal } \\
\text { villi with } \\
\text { villous } \\
\text { atrophy on } \\
\text { biopsy }\end{array}$ & Up to $x 150$ & $\begin{array}{l}\text { No comparison with } \\
\text { standard endoscopy } \\
\text { Endoscopic markers not } \\
\text { identified } \\
\text { Sensitivity and } \\
\text { specificity of } 98 \% \text { and } \\
100 \% \text {, respectively }\end{array}$ \\
\hline $\begin{array}{l}\text { Niveloni et } \\
\text { al [6] }\end{array}$ & 1998 & Argentina & $\begin{array}{l}\text { Applied } 5 \mathrm{ml} 1 \% \\
\text { methylene blue }\end{array}$ & $\begin{array}{c}167 \\
\text { (80 with VA) }\end{array}$ & 3 & $\begin{array}{l}\text { Endoscopic } \\
\text { markers } \\
\text { with villous } \\
\text { atrophy }\end{array}$ & $\begin{array}{l}\text { No } \\
\text { magnification }\end{array}$ & $\begin{array}{l}\text { Endoscopic markers } \\
\text { seen before and after dye } \\
\text { in all cases } \\
\text { Sensitivity and } \\
\text { specificity of } 94 \% \text { and } \\
99 \% \text {, respectively }\end{array}$ \\
\hline $\begin{array}{l}\text { Ravelli et } \\
\text { al [7] }\end{array}$ & 2001 & Italy & $\begin{array}{l}\text { Applied } 5-10 \mathrm{ml} \\
1 \% \text { methylene } \\
\text { blue to D2 }\end{array}$ & 20 & $\begin{array}{l}1 \text { (presence of } \\
\text { markers was agreed } \\
\text { with one other } \\
\text { gastroenterologist) }\end{array}$ & $\begin{array}{l}\text { Endoscopic } \\
\text { markers }\end{array}$ & $\begin{array}{l}\text { No } \\
\text { magnification }\end{array}$ & $\begin{array}{l}\text { Endoscopic markers } \\
\text { seen before and after dye } \\
\text { in all cases }\end{array}$ \\
\hline
\end{tabular}

D1 - First part of the duodenum, D2 - Second part of the duodenum, CD - Coeliac Disease, VA - Villous Atrophy

Corresponding author: Alexander Johnston mda09aj@sheffield.ac.uk

\section{Conflicts of interest: None.}

${ }^{*}$ Previous Presentation: This study was presented as a poster abstract at the 2013 British Society of Gastroenterology Annual Meeting; June 25, 2013; Glasgow, United Kingdom.

\section{REFERENCES}

1. Stevens F, McCarthy CF. The endoscopic demonstration of coeliac disease. Endoscopy 1976;8:177-180.

2. Siegel LM, Stevens PD, Lightdale CJ, et al. Combined magnification endoscopy with chromoendoscopy in the evaluation of patients with suspected malabsorption. Gastrointest Endosc 1997;46:226-230.
3. Kiesslich R, Mergener K, Naumann C, et al. Value of chromoendoscopy and magnification endoscopy in the evaluation of duodenal abnormalities: a prospective, randomized comparison. Endoscopy 2003;35:559-563.

4. Morishita T, Kamiya T, Ishii H. Magnifying endoscopy of the duodenum with dye scattering method in a case with celiac disease. Arq Gastroenterol 2003;40:110-113.

5. Iovino P, Pascariello A, Russo I, Galloro G, Pellegrini L, Ciacci C. Difficult diagnosis of celiac disease: diagnostic accuracy and utility of chromo-zoom endoscopy. Gastrointest Endosc 2013;77:233-240.

6. Niveloni S, Fiorini A, Dezi R, et al. Usefulness of videoduodenoscopy and vital dye staining as indicators of mucosal atrophy of celiac disease: assessment of interobserver agreement. Gastrointest Endosc 1998;47:223-229.

7. Ravelli AM, Tobanelli P, Minelli L, Villanacci V, Cestari R. Endoscopic features of celiac disease in children. Gastrointest Endosc 2001;54:736742. 